\title{
International Comparison and Reference of Cultivating Internationalized Talent for Human Resources Management of University
}

\author{
Hao-yu HUANG ${ }^{1, a,{ }^{*}}$ and Jin-han ZHOU ${ }^{1, b}$ \\ ${ }^{1}$ Wuhan Univ Technol, Sch Management, Wuhan 430070, People R China \\ a757995713@qq.com, b2293434516@qq.com
}

\begin{abstract}
Keywords: Human Resources Management, Cultivating Internationalized Talent, International Comparison.
\end{abstract}

\begin{abstract}
In order to meet the demands of the economic globalization, it is important to cultivate the internationalized talent in the human resource major to cope with different kinds of the internationalized talent. Based on this, the paper aims to analyze the concurrent situation, the main problems and their reasons of the traditional cultivating model of the internationalized talent in Human Resources Major of Cinese university. Then the paper put forth the ecological cultivating model of the internationalized talent in Human Resources Major.
\end{abstract}

\section{Introduction}

As we all know, the economic globalization need international talents as support [1]. The most basic function of higher education is the cultivating talents, only the universities make sure of the implementation of internationalized talents cultivation concept, can help the China's higher education internationalization developing process [2]. Therefore, our research consider that the internationalized talent in human resources major of Chinese university is the professional talents which be able to show their talents well, have international vision, professional knowledge, innovation quality, adapt the international rules and cross-cultural communication ability in the globalization human resource management domain.

After decades of exploration and development, Chinese university human resources management has formed a new pattern with larger scale and multiple field. But because of the problem about unclearly cultivate target, unattractive talent introduction, poor conditions of facilities and lack of systematic layout at present stage, the human resources management of Chinese universities need to face with the situation about low-rise international reputation, low education quality recognition and the relatively weak international competitiveness [3]. Therefore, our research based on the perspective of cultivating subject, analysis the current situation and problems about the internationalized talents cultivation of Chinese university human resources management, through the international comparison and reference of world-class universities internationalized talents cultivation, propose the targeted feasibility suggestions.

\section{The Status Analysis of Cultivating Internationalized Talent for Human Resources Management of Chinese University}

From the specific implementation, we can see that for most universities in China, the practice of human resource management cultivating internationalized talents is just 
focus on parts of the cultivating process, and lack of the overall layout. Although at the beginning of cultivating internationalized talent, the effect maybe significantly, but it's easy to hit [4].

\section{The Unclear Orientation of International Talent Cultivation Consciousness}

Various universities in China established Human Resources Major and began to integrate the internationalization and globalization concept in the cultivation objectives. But in the actual cultivation process, however, many universities still stay in let students mastering a foreign language and being able to simple academic communication, compared with the foreign first-class universities' cultivation objectives to develop students to own ability of "to promote the global economy", or "the leadership talent world needs ". For this, Chinese universities still have a big gap with them .

\section{The Existing Gap of International Faculty Level}

Diversified teaching staff and academic atmosphere is the basic conditions to improve the internationalization talents cultivation. On the one hand, for the universities "Go out", set the young teachers abroad to learn in first-class universities and research institutions, get the cutting-edge ideas and cross-cultural thinking, in order to improve the international qualifications of themselves. On the other hand, "Take in", to bring in the foreign experts and scholars, academic ideas and teaching mode, in order to enhance the level of local teachers. But conditioned by many factors in existing stage, most of Chinese universities are difficult to hire the professional human resources management experts and professors who owned the rich experience for internationalization course teaching or cooperation project.

\section{The Deficient Effect of Internationalization Curriculum Provision}

Under the background of globalization, Chinese universities' human resources major added the curriculum, such as transnational human resources management, cross-cultural communication, professional English and other professional internationalization courses, with the purpose of that through the curriculum innovation to cultivate students master the internationalization and diversified professional skills.

However, from the bondage of the original system, many universities although set up the professional course called "internationalization", but the actual content, teaching system even the practical training all like the "old wine in new bottles", there is no change with traditional curriculum.

\section{Being Given Priority With Output of International Cooperation and Communication}

At present, the international exchanges and cooperation pattern in Chinese universities mainly have the following three types: First is based on the University Union, expand the global academic communication channel; Second is to focus on highlighting subject advantages and regional advantages, establish international industry - university research cooperation strategic alliance; Third is to expand channels attracting international students. In 2014, Chinese scholars published 65,000 international cooperation papers, a year-on-year increase of 9372 articles, ascend by $16.7 \%$, approximately $24.7 \%$ of the total number of SCI papers published in China [5]. But Chinese universities still had been a lack of attractive for overseas scholars and students, by the data published by ministry of education in 2014,the foreign students only accounted for $0.7 \%$ of total college students[6], but in the United States, international 
students accounted for $4.8 \%$, far higher than the proportion of students in Chinese universities [7].

\section{The International Comparison of Cultivating Internationalized Talent Pattern for Universities in the Developed Countries}

\section{Oxford, "Comprehensive Driven" Cultivating Internationalized Talent Pattern}

British education historian John Darwin put forward four quantifiable indicators to measure the degree for the internationalization of university: First, leading international academic reputation; second, sufficient funding; third, widely developing academic exchanges and cooperation projects on global scale; Forth, attract international faculty and recruit international students[8]. In recent years, Oxford always follow the above indexes proceeding international construction, and thereby established the status of the world's top university.

The Historical Inheritance of International Target Orientation. For Oxford University, international students have been admitted to as early as 1190, Over the years, through such as expanding the international students market, promote the internationalization reform of curriculum, led by regional or global international cooperation project among the top universities in the world and such strategies to get the forefront of the world first-class university internationalization development level. Oxford University always attaches importance to the implementation of the internationalization development strategy, setting up international strategic office, mainly take charge of developing coherent strategy, overall management of international affairs and expanding international academic exchange and education cooperation, in order to improve Oxford University's international image and enhance the international competitiveness.

The Mature International Faculty. According to the statistics, Oxford University have more than $40 \%$ foreign teaching faculty in scientific research team, and from nearly hundred countries and regions. The current number of world famous scholar hired in Oxford ranked the first place on the UK universities. In the process of teachers' employment, Oxford University has always been insisting the ability standard preferred, established professional screening recruitment mechanism to recruiting and selecting outstanding individuals and teams over the world.

World First-Class of Discipline Curriculum Construction. In recent years, under the guidance of international target orientation, Oxford made big changes in the internationalization curriculum part, overall demonstrated three characteristics: First is curriculum quality and teaching level has reached the international advanced level; The second is curriculum content in line with international standards; Third is that the curriculum era characteristic clear-cut. Since the 21st century, Oxford University multiple disciplines of social science and natural science developing rapidly and owned the leading scientific research level, which laid a foundation for professional internationalization curriculum setting and also effectively promote the competitiveness of attracting international students come to Oxford University.

Comprehensive International Exchanges and Cooperation. In recent years, Oxford put more funds and policy support into international admissions market competition, so the international students enrolled in quantity and quality have different degree of ascension. By 2014, the proportion of international students has exceed a quarter, while for postgraduate students, the proportion reached more than half. In international 
cooperation part,Oxford University participate in interdisciplinary scientific research cooperation projects all over the world. Oxford University lead to set up multiple international alliances or groups with global influence, including the University Union, etc.

\section{Yale, " The Global University" Cultivating Internationalized Talent Pattern}

Into the 21 st century, Yale President Richard Levin proposed that constructing Yale to being "truly global university", and successively promulgated the Yale internationalization strategic framework in 2005-2008 and the Yale internationalization strategic framework and acting plans in 2009-2012, the two guiding documents guided the focus, direction and path of Yale internationalization development, established the foundation of Yale University international activities [9].

Set Up The Framework System of International Target. Around the purpose of cultivating global leaders, Yale University refined international development target into three measurable indicators: (1) cultivating students' ability of professional skills and provide services in globalization; (2) be able to attract the world's top academics and students to join; (3) set up the world-class university status and reputation. Under the background of globalization, Yale University should base on existing research superiority, promoting the global research project cooperation, deepening cross-cultural and cross-disciplinary academic exchanges, enhancing international high-quality talent reserves, in order to elevate Yale University's competitiveness in the higher education system over the world.

Expand Investment for International Faculty. At present, Yale University owned more than thousands of international exchanges and cooperation projects, and increasing support for sending teachers to participate in global scientific communication year by year. Yale scholars apply for overseas academic research activities will get the different levels of research funding from the Yale international and regional research center, at the same time, Yale University facing global recruit the international famous experts and scholars all the year round, in order to satisfy the demands of international teaching and scientific research. As shown in table 1, the overseas teachers of Yale University accounted for more than 54\%, the mature internationalization can not only accelerate the steps of internationalization construction of Yale University, but also promote the international influence of Yale University.

Table 1. The number of Yale University's overseas teachers statistics in 2010-2015.

\begin{tabular}{|c|c|c|c|c|c|}
\hline & $2010-2011$ & $2011-2012$ & $2012-2013$ & $2013-2014$ & $2014-2015$ \\
\hline $\begin{array}{c}\text { The foreign } \\
\text { teachers number }\end{array}$ & 2065 & 2239 & 2327 & 2396 & 2457 \\
\hline $\begin{array}{c}\text { The total full-time } \\
\text { teachers number }\end{array}$ & 3810 & 3953 & 4140 & 4147 & 4410 \\
\hline $\begin{array}{c}\text { Foreign teachers } \\
\text { proportion (\%) }\end{array}$ & 54.19 & 56.64 & 56.21 & 57.78 & 55.71 \\
\hline $\begin{array}{c}\text { Covered the nations } \\
\text { number }\end{array}$ & $90+$ & $90+$ & $90+$ & 96 & 97 \\
\hline
\end{tabular}

Note: data from: http://www.yale.edu/oir/factsheet.html.

Promote The Continuous Improvement of Internationalization Course. According to the statistics, Yale University has already set up more than 600 interdisciplinary internationalization courses, mainly divided into three types: First is the 
internationalization courses related to professional knowledge; Second is the courses aimed to discuss the international frontier research; Third is based on the internationalization professional needs to add the language and culture courses. In order to promote students' cross-cultural communication ability, Yale University set up as many as 31 kinds of foreign language courses for students to choose. At the same time, Yale University also perennial invited the world's top experts to give lectures, especially in the field of interdisciplinary research, help students to enhance the level of international quality.

Expand the Enrollment Scale of International Students. In recent years, in order to expand the scale of international admissions, Yale formulates flexible and practical international admissions and funding plans for each collage, such as " need-blind admission" and "need-based financialaid", equipped with specialist one-to-one review, according to the actual needs of students given corresponding scholarship funding guarantee. Since 2010, quality improved steadily with Yale university's international students, international students number risen from 1989 in 2010 to 2477 in 2016 , the growing rate nearly $25 \%$, international students accounted for the proportion of students ascended from $17 \%$ to $20 \%$.

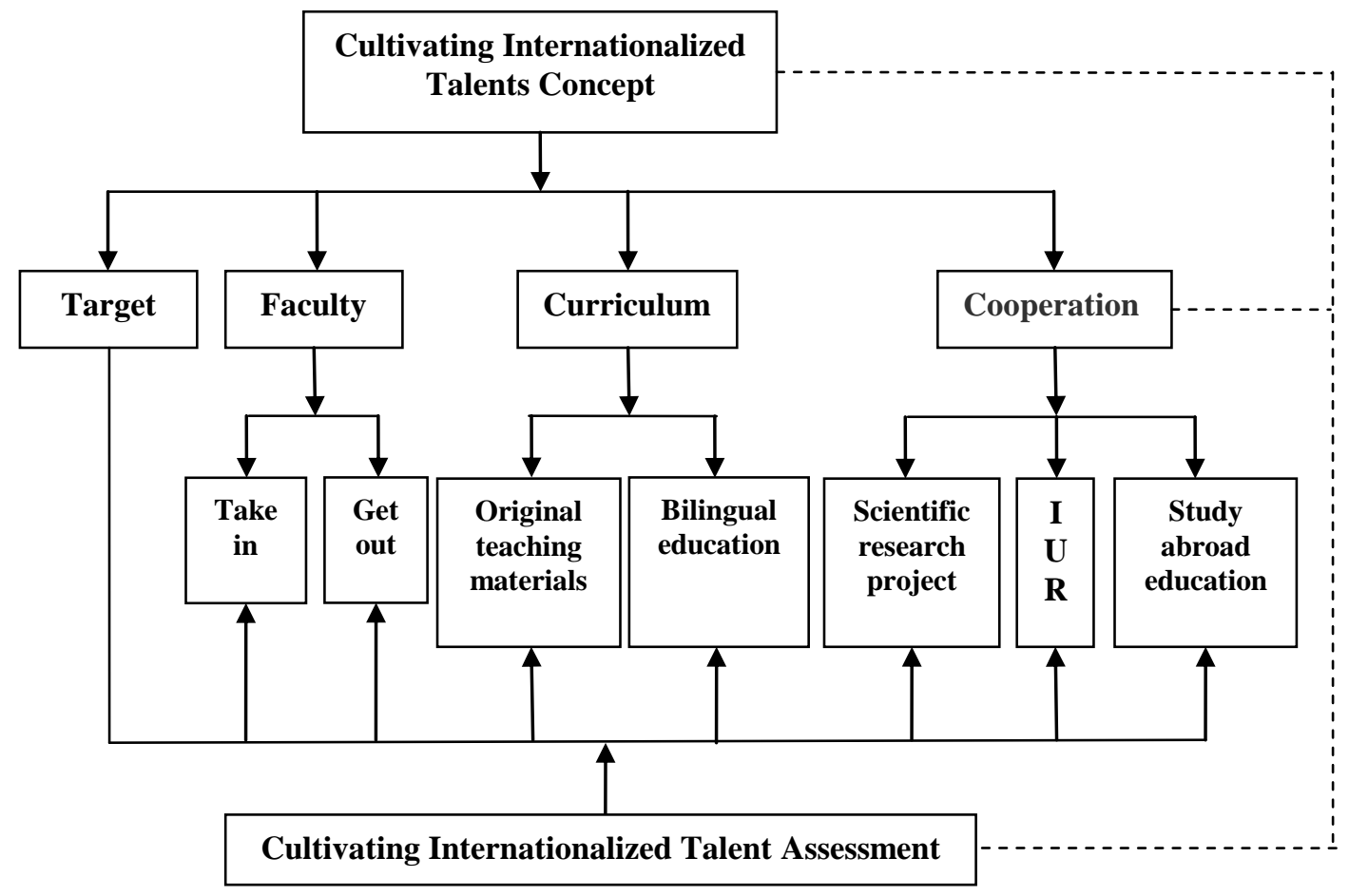

Fig. 1. Cultivating international talents system of human resource major

\section{The Ecological Cultivating Model of University Internationalized Talent in Human Resources Major}

Compared with the developed countries, it generally started relatively late for cultivating internationalized talents of human resource major in Chinese universities. The existing gap with cultivating internationalized talents cannot be overlooked. Therefore, it is necessary to draw lessons from foreign successful experience, building the cultivating pattern conforming to the requirements of our society, cultivating international talents which have solid theoretical foundation, strong practical ability and outstanding innovative spirit as soon as possible [10]. Based on this, this article argues 
that universities need constituting a complete internationalized talent cultivation system from four aspects, including international target orientation, faculty, curriculum provision and cooperative communication, as shown in figure 1.

\section{Conclusions}

To sum up, only by constantly exploring and innovating the cultivating internationalized talents pattern of human resource major, building internationalized talent cultivation pattern in order to realize the goal that cultivating students' international vision and innovative practice ability, can promoting the cultivating internationalized talents level of human resource major in Chinese universities. Therefore, Chinese universities in the future should be focused on cultivating students in human resource major being the compound talents who have theoretical knowledge, innovative thinking and international vision of ability, in order to fulfill the rapidly social and economic development for the demand of internationalized human resource management talents.

\section{Acknowledgement}

This research was financially supported by the National Social Science Foundation of China (14BGL200), Teaching Research Fund Project (w2014020) and the Fundamental Research Funds for Central University (2015-VI-001).

\section{References}

[1] J.B. Lu and X. Li, Research on Chinese University's Talent Education: based on the Case Study of Wuhan University, Wuhan University Journal (Philosophy \& Social Sciences) (2009). (In Chinese)

[2] Teichler, Ulrich.The Changing Debate on Internationalisation of Higher Education. Higher Education, 48.1(2004):5-26.

[3] Y. Sun, Path Analysis on the Internationalization of Higher Education Customized Training Mode, Theory and Practice of Education (2015): 30-33. (In Chinese)

[4] Y.Y. Xin and H. Ni, International Talents Connect the "Belt and Road Initiative":Roles Demands and Strategies, Journal of Higher Education Management (2016). (In Chinese)

[5] X.M. Dong, W.U. Wen-Ying,and L. I. Xiao-Chen, Research and Practice of International Talent Taining Mode in Local Colleges and Universities, Research \& Practice on Higher Education (2014). (In Chinese)

[6] M.C. Vance, I. Chow and Y. Paik, Analysis of Korean expatriate congruence with Chinese labor perceptions on training method importance: implications for global talent management, The International Journal of Human Resource Management (2013):985-1005.

[7] K.L. Oyler, Higher education goes global: A comparative study of internationalization at an American and Australian university, Dissertations \& Theses Gradworks (2009). 
[8] Y.Z. Wang and T.W. Xu, Internationalization of American Higher Education and Its Production of Applied Talents, Journal of Higher Education Management (2012).(In Chinese)

[9] X.Shan, Comparison of the Internationalization Strategies between Yale University and Harvard University, Comparative Education Review (2012). (In Chinese)

[10] J. Zhang, Research and Practice on the 'Yi Jing Si Tong' Concept in Universities for Cultivating International Talents in a Local-for-global Way, Journal of National Academy of Education Administration (2014). (In Chinese) 